\title{
Heligmosomoides bakeri: a model for exploring the biology and genetics of resistance to chronic gastrointestinal nematode infections
}

\author{
J. M. BEHNKE ${ }^{1 *}$, D. M. MENGE ${ }^{2}$ and $\mathrm{H}$. NOYES ${ }^{3}$ \\ ${ }^{1}$ School of Biology, University of Nottingham, University Park, Nottingham NG7 2RD, UK \\ ${ }^{2}$ Center for Infectious Diseases and Microbiology Translational Research, University of Minnesota, MTRF 2001 th St SE, \\ Minneapolis MN 55455, USA \\ ${ }^{3}$ School of Biological Sciences, Biosciences Building, University of Liverpool, Crown Street, Liverpool L69 7ZB, UK
}

(Received 2 Fanuary 2009; revised 17 February 2009; accepted 17 February 2009; first published online 19 May 2009)

SUMMARY

The intestinal nematode Heligmosomoides bakeri has undergone 2 name changes during the last 4 decades. Originally, the name conferred on the organism in the early 20th century was Nematospiroides dubius, but this was dropped in favour of Heligmosomoides polygyrus, and then more recently H. bakeri, to distinguish it from a closely related parasite commonly found in wood mice in Europe. H. bakeri typically causes long-lasting infections in mice and in this respect it has been an invaluable laboratory model of chronic intestinal nematode infections. Resistance to H. bakeri is a dominant trait and is controlled by genes both within and outside the MHC. More recently, a significant QTL has been identified on chromosome 1, although the identity of the underlying genes is not yet known. Other QTL for resistance traits and for the accompanying immune responses were also defined, indicating that resistance to $H$. bakeri is a highly polygenic phenomenon. Hence marker-assisted breeding programmes aiming to improve resistance to GI nematodes in breeds of domestic livestock will need to be highly selective, focussing on genes that confer the greatest proportion of overall genetic resistance, whilst leaving livestock well-equipped genetically to cope with other types of pathogens and preserving important production traits.

Key words: Heligmosomoides bakeri, Heligmosomoides polygyrus, Nematospiroides dubius, immunity, resistance, genetics, quantitative trait loci.

\section{INTRODUCTION}

The end of the 20th century and the first decade of the 21 st have seen unprecedented progress in many different areas of the biological and medical sciences, and genetics in one form or another has been central to most. In this paper, with the help of my coauthors, I (J. M. B.) take a personal look back over the last 38 years of my research career, at the history of the genetic exploration of my favourite organism, the intestinal nematode of mice, Heligmosomoides bakeri. But why H. bakeri?

Much of what we know about the mechanisms of resistance to intestinal nematodes and other helminths is derived from research on laboratory model systems, which can be conveniently dissected at a variety of highly sophisticated levels. Most helminths show absolute or narrow host specificity, and rodent host-parasite systems therefore provide a convenient and much cheaper alternative to livestock, and facilitate faster progress over a shorter time-frame than would be possible with, for example, sheep. Human

\footnotetext{
* Corresponding author. Tel: +44 (0)115 9513208. E-mail: jerzy.behnke@nottingham.ac.uk
}

intestinal nematodes are mostly highly specific to man, and cannot be directly explored in animal systems. Ethical considerations obviously limit what can be done in humans themselves. Rodent systems have therefore provided the backbone to research in this field and facilitated the development of paradigms for mechanisms of resistance. Predictions stemming from the resulting hypotheses can then be tested in humans and livestock, albeit with less precision.

However, there is one important difference between infections in humans/livestock and rodents. Although there are exceptions, the majority of naturally acquired nematodes affecting humans/ livestock form long-lasting chronic infections. In contrast under experimental single-pulse infection regimens, at the typically used relatively high dose rates, those of rodents are terminated rapidly, worms being expelled within 3 weeks of infection (Behnke, 1987), and these have been exploited widely to dissect the underlying host-protective mechanisms. Lower dose levels can allow some rodent nematodes, such as Trichuris muris and Nippostrongylus brasiliensis, to survive for longer and even to cause chronic infections, but generally these combinations have attracted 
less attention (Jenkins and Phillipson, 1971; Behnke and Wakelin, 1973; Bancroft et al. 1994). This is where $H$. bakeri is most important. In contrast to other rodent-model systems, adult $H$. bakeri cause long-lasting infections even at high infection intensities, and therefore provide a useful model for exploring why and how host-protective mechanisms, known to be present in the intestinal mucosa, fail in the case of this species, and by inference in relevant species affecting humans and livestock. The life cycle of $H$. bakeri has many similarities to those of the economically important trichostrongyloid nematodes of sheep and cattle, and with anthelmintic resistance to parasites of livestock spreading globally, breeding for resistance is seen as an important strategy for controlling nematode infections in the future. $H$. bakeri provides a convenient model for exploring the genetic basis of resistance in chronic intestinal nematode infections.

Stimulated by recent episodes of refereeing for various journals, first we will endeavour to recount some aspects of the history of research on this parasite, which seem to have been largely forgotten. We do so to inform future generations of parasitologists investigating the fascinating biology of $H$. bakeri. We urge them to be aware that $H$. bakeri has changed its name twice already during the last 4 decades, and that there is a wealth of information in the public domain on this parasite recorded under its previous names.

HELIGMOSOMOIDES BAKERI OR H. POLYGYRUS OR NEMATOSPIROIDES DUBIUS: ONE SPECIES, TWO SPECIES, OR MORE?

One of the oldest laboratory models of intestinal nematode infections is the parasite now known as H. bakeri. There are as yet few publications referring to it as $H$. bakeri, because for the last 38 years or so it has been referred to mostly as $H$. polygyrus or $H$. polygyrus bakeri, and before that it was known as Nematospiroides dubius. Its earlier history, mostly long forgotten, is even more confusing and its taxonomic status has changed as we have learned more about its fascinating biology and, in particular, its genetics. The central issue has been the conflict in what to call the common intestinal heligmosomatid of European wood mice, Apodemus sylvaticus, and that isolated from the Nearctic deer mouse Peromyscus maniculatus (Forrester and Neilson, 1973), whose normal host in North America is actually the house mice (Mus musculus). Superficially, they are very similar and can only be distinguished reliably by careful scrutiny of the cuticular structures (the longitudinal ridges called crêtes) or more recently by molecular techniques as well (DuretteDesset et al. 1972; Cable et al. 2006).

Records of a common intestinal nematode in wild wood mice from Europe go back to the start of the last century, under a variety of names, until some degree of conformity ensued when Baylis (1926, 1927) named it Nematospiroides dubius. The parasite now maintained in laboratory mice appeared in the scientific literature for the first time in the 1940s, when Spurlock (1943) reported using N. dubius Baylis isolated from house mice (Mus musculus musculus) in California in 1939. Other workers went on to use the line established much later, in the 1950 s by Ehrenford (1954; strain 50), with larvae derived from an incidental infection in Peromyscus maniculatus gambeli. It is most likely (although uncertain in the mists of time) that it was this line that was sent to the Wellcome Foundation in London in the 1950s, and then distributed to laboratories around the world as a useful laboratory model. In those early days, authors used $N$. dubius for both the laboratory-maintained isolate in lab mice and for the parasite encountered in wood mice, and the two were considered to be one species.

It was probably Forrester (1971) who first popularised the name Heligmosomoides polygyrus (based on Dujardin, 1845), and in the years that followed American workers in particular began to refer to the mouse-passaged isolate as $H$. polygyrus (=Nematospiroides dubius) (Crandall et al. 1974; Cypess and Zidian, 1975 ; Shimp et al. 1975), but N. dubius continued to be used until well into the 1980s (Enriquez et al. $1988 c$ ). Thus, there is a wealth of literature on the immunology, host-parasite relationship and biology of this nematode from those days, in which the parasite was referred to as $N$. dubius: this is not always appreciated by current workers in the field. Keying into search engines the terms Heligmosomoides, $H$. polygyrus or $H$. bakeri does not pick up Nematospiroides dubius.

In the meantime, other closely related nematodes from wild rodents had been assigned to the genus Heligmosomoides (Asakawa, 1988), and it became necessary to rename the parasite. This early history was reviewed by Behnke et al. (1991), who recommended that the use of the name Nematospiroides dubius be finally abandoned once and for all.

The idea that the parasite maintained in laboratory mice might be a different animal to that in wood mice had been suggested two decades earlier but was largely ignored (Forrester, 1971). Durette-Desset et al. (1972) proposed that they should be conveniently regarded as subspecies and referred to as $H$. polygyrus bakeri for the line in laboratory mice (named after N. F. Baker, one of the earliest workers on this species; Baker, 1954), and H.polygyrus polygyrus for that in wood mice. With increasing knowledge and understanding of the morphological, enzymatic, antigenic and molecular differences between these 2 'subspecies' (Quinnell et al. 1991; Abu-Madi et al. 1994, 2000), it became clear over the years that they were in fact 2 distinct species (Tenora and Barus, 2001 ; Tenora et al. 2003). They were both raised to 
species status by Cable et al. (2006) on the basis of recent molecular genetic data: $H$. polygyrus for the parasite in wild wood mice, and $H$. bakeri for that passaged in laboratory mice. That was already 3 years ago, and yet we still see the use of $H$. polygyrus in the current immunological literature. Whilst happy to accept that cell-surface determinants can change as we learn more about their molecular structures and inter-relationships, there seems a deep inertia to accepting that taxonomy and the systematics of parasites are also legitimate sciences in their own right, and that progress necessitates reclassification and the renaming of the key players.

\section{H. BAKERI AS A MODEL FOR CHRONIC INTESTINAL NEMATODE INFECTIONS}

Stimulated by a report from Ackert et al. (1935) that different breeds of poultry varied in their resistance to Ascaridia lineata, and at a time when little was known about variation in resistance between breeds of hosts, it was Spurlock's (1943) pioneering studies that first established $H$. bakeri as an excellent laboratory model for exploring resistance to intestinal nematode infections in mice. Even at this early stage, the genetics of the response was a key theme in his work. The 2 mouse strains that he compared (A-W and C-57) differed in their tolerance of heavy infections and capacity to support worms for a period of 5 months. Right from the start it became obvious that $H$. bakeri differed markedly from other murine intestinal nematodes in so far as primary infections were tolerated by mice for very long periods of time. Whereas nematodes such as Nippostrongylus brasilensis and Trichinella spiralis lasted only 2-3 weeks in the guts of their hosts when administered at typical relatively high dose rates, $H$. bakeri could survive for 10 months (Day et al. 1979; Robinson et al. 1989).

As the parasite was passed around the research laboratories of the world, it saw increasing popularity, although in those days it was mostly still known as $N$. dubius. Liu (1966) carried on with the genetic theme, comparing the resilience of different mouse strains to heavy infections and recording the lethal dose levels for each, but also establishing some of the incredibly useful assets of this model. He found that larvae could be stored at $4{ }^{\circ} \mathrm{C}$ for months on end, and $50 \%$ infectivity was retained even after 30 weeks of storage at this temperature. He reported that more than $90 \%$ of fresh infective larvae establish in mice when they were exposed for the first time to infection with this species, and showed that mice retained worms for over 30 weeks after inoculation. $H$. bakeri was therefore easy to maintain since it did not have to be passaged as frequently as the other species; it was usually enough just to infect a batch of mice and keep them for most of the year, with backup stocks of infective larvae in the fridge (Kerboeuf, 1978).
Colin Dobson (1961) also began to work on the species in Sheffield in the UK in the 1960s, before devoting most of his subsequent career in Brisbane to investigating genetic and immunological aspects of infection with $H$. bakeri (Brindley and Dobson, 1982; Dobson, 1982; Brindley et al. 1986; Zhong and Dobson, 1996). Throughout the majority of his publications (excepting those in the 1990s), Dobson and his co-workers referred to the parasite as $N$. dubius: they generated a large literature on the parasite, seldom referred to these days (reviewed by Monroy and Enriquez, 1992).

One of Dobson's most important and unique achievements was the development of lines of $H$. bakeri with varying sensitivities to the murine immune response, indicating that the capacity of the parasite to cause chronic infections was itself under genetic control (Dobson and Tang, 1991; Tang et al. 1995). Chehresa et al. (1997) then showed that if the parasite was passaged separately in different lines, without mixing, within 10 generations distinct lines emerged that differed in aspects of their life histories. Njoroge et al. (1997) selected lines for enhanced resistance to the anthelmintic drug ivermectin, and succeeded in increasing the resistance by 1.5 times that of the susceptible line by the $8-15$ th generations. All these studies indicate that the laboratorypassaged H. bakeri may not be entirely homozygous at all genetic loci, and that there is scope for genetic variation within the parasite even $40-50$ years after isolation from the wild.

H. BAKERI AS A MODEL FOR THE BIOLOGY OF INTESTINE-DWELLING WORMS

The basic features of the life cycle of $H$. bakeri were worked out early on by Spurlock (1943) and Ehrenford (1954). However, additional pieces were contributed to the story right through to the $1990 \mathrm{~s}$. The pre-parasitic stages were studied by Fahmy (1956), but evidence for the principal route of transmission in the wild was provided almost 40 years later: Hernandez and Sukhdeo (1995) showed that infective larvae are acquired from host hair during grooming activities (Hernandez and Sukhdeo, 1995). These exsheath in the stomach and first invade the gastric mucosa, but then move to the small intestine where by the third day they have localized in the intestinal walls (Liu, 1965; Sukhdeo, O'Grady and Hsu, 1984). Initially, the larvae develop beneath the serosa in the muscularis externa and are able to sit unharmed in the gut wall in this location in immune mice, despite the intense granulomata that develop around them (Cypess et al. 1988; Morimoto et al. 2004). They manage to survive for quite long periods of time in a state resembling arrested development (Behnke and Parish, 1979a). The in vivo developmental stages and moult times were described in detail by Bryant (1973). The worms return to the gut 
lumen as pre-adults on days $9-10$, and reside in the anterior of the small intestine. The parasite's preference for this location was reported by Lewis and Bryant (1976), but not explained convincingly until Bansemir and Sukhdeo (1996) showed that the height of the villi around which they wrap their highly coiled bodies was the key factor determining where the adults reside in the gut: villi are longer in the duodenum and anterior jejunum compared with lower down in the ileum. Some workers had interpreted the red colour of the adult worms as evidence of feeding on host blood, but in fact the pigment is derived from the worms themselves, and they feed neither on gut contents nor blood, but rather on the mucosal cells (Bansemir and Sukhdeo, 1994).

H. BAKERI AS A MODEL FOR EXPLORING THE GENETICS OF THE HOST RESPONSE TO CHRONIC INTESTINAL NEMATODE INFECTIONS

By the 1970s inbred strains of mice had become well established and some were well characterized. There was, however, one major drawback to the study of $H$. bakeri: most conventional and popular strains of mice were not able to remove the adult worms, and hence tolerated long chronic infections (Bartlett and Ball, 1972; Robinson et al. 1989) without easily developing acquired immunity to challenge infections. Mouse strains such as $\mathrm{C} 57 \mathrm{BL} / 10, \mathrm{C} 57 \mathrm{BL} / 6, \mathrm{C} 3 \mathrm{H}$ and CBA, all popular strains in immunological research, sustained long chronic infections with $H$. bakeri, even though they were able to resist other parasites such as T. spiralis and Trichuris muris on a much shorter time-scale (Wakelin, 1978). Adult worms could survive for about 46 weeks after infections in these strains, and this period probably reflects the maximum lifespan of the worm (Behnke et al. 1987). Even BALB/c mice endured infections lasting many weeks, although in this strain infections were shorter in duration and it became evident that the size of the intestinal worm burden was a critical factor in determining how long it would take for the worms to be cleared (Robinson et al. 1989). Lowintensity infections were removed by mice more rapidly than high-intensity infections (Dobson et al. 1985). Equally interesting and counter-intuitively, high-intensity infections lasting into the adult phase were less immunogenic than much shorter infections terminated during the tissue phase of development (Behnke and Robinson, 1985; Dobson et al. 1985; Enriquez et al. 1988 c; Fakae et al. 2000). These observations suggested that adult worms were downregulating protective immunity.

In fact, earlier studies had already shown that adult worms have a potent immunodepressive influence on the mouse host (Shimp et al. 1975; Ali and Behnke, 1983, 1984), but especially on the intestinal environment. In this way $H$. bakeri could facilitate its own survival for extraordinarily long periods in mouse strains otherwise totally competent immunologically (Behnke et al. 1983; Behnke, 1987), a strategy now known to be utilized by many other nematodes and other helminths that cause longlasting chronic infections (Behnke et al. 1992; Maizels et al. 2004). Even strains having the capacity to generate a potent mastocytosis in response to infection with $T$. spiralis, failed to do so when they harboured H. bakeri (Dehlawi et al. 1987; Dehlawi and Wakelin, 1988) and the generation of both CD8 + and CD4 + T cells to heterologous infections was greatly suppressed (Khan et al. 2008). This immunosuppressive effect allowed other species of parasites, which normally would have been expelled, to survive for much longer periods in concurrently infected mice (Colwell and Wescott, 1973; Courtney and Forrester, 1973; Della Bruna and Xenia, 1976; Behnke et al. 2001). Adult worms also reduced inflammation to intestinal bacterial infections, such as those caused by Helicobacter pylori (Fox et al. 2000), influx of eosinophils into the lungs of asthmatic mice (Rzepecka et al. 2007) and even to chemically induced chronic colitis (Elliott et al. 2004). The basis of the immunosuppressive mechanism has been explored by many different groups (Telford et al. 1989; Crawford et al. 1989; Pleass and Bianco, 1994; Rzepecka et al. 2006; Doligalska et al. 2006). Recent attention has returned to an idea originally suggested 25 years ago (Pritchard et al. 1984) that through their excretory/secretory products the worms induce cells that down-regulate the immune response by affecting dendritic cells and the induction of IL-10 secreting T cells (Elliott et al. 2004; Wilson et al. 2005 ; Rzepecka et al. 2007; Segura et al. 2007). In particular, the idea that regulatory $\mathrm{CD} 4{ }^{+} \mathrm{CD} 25^{+} \mathrm{T}$ cells come to dominate the immune response later during infection and this may be due to the presence of a functional mimic of TGF $\beta$ in the secretion of the adult worms that enhances Foxp3 expression on $\mathrm{CD}^{+}{ }^{+} \mathrm{T}$ cells (R. Maizels - personal communication), has generated keen interest in this hostparasite relationship as a model for investigating the role of helminths in allergy and asthma (Finney et al. 2007). However, this is unlikely to be the full story, because adult worms transplanted into immune mice, manage to survive for quite long periods of time (Robinson et al. 1988) and, given that the secondary response can be generated within just a few days, this survival is unlikely to be facilitated by the induction of new regulatory T cells. Even today there is no consensus on what it is that the parasite secretes/expresses to impair/divert the host's capacity to generate the potent intestinal inflammatory response (Pritchard and Behnke, 1985) to which the adult worms are ultimately susceptible (Behnke $e t$ al. 1992). Clearly, the parasite's strategy for long-term survival is to prevent this response being initiated in the first place, but exactly how this is achieved is still largely unknown. 
Once it was appreciated that the immunosuppressive influence was principally derived from adult worms, and that the histotropic larvae provided the strongest signal for acquired immunity (Panter, 1969; Wahid and Behnke, 1992), simpler immunizing protocols were introduced, based on terminating infections during the tissue phase of infection or eliminating adult worms as soon as they emerged from the tissues. These protocols were even successful at inducing strong immunity in mouse strains that could not previously be immunized by repeated infections (e.g. Wahid and Behnke, 1996).

The first inbred strain to show an unusually high level of resistance to challenge was a little-known strain called NIH (Behnke and Wakelin, 1977), but even this strain was not able to remove primary infection adult worms easily (Behnke and Robinson, 1985). Cypess et al. (1977) reported on a hybrid strain (LAF1) able to clear up to $50 \%$ of adult worms by 3 weeks after infection, and Prowse et al. (1979) and Mitchell et al. (1982) identified the inbred $\mathrm{SJL}$ strain as one that removes adult worm infections rapidly, in contrast to other mouse strains. Then the SWR strain was discovered, and in dramatic contrast to all other popular strains, these two (SJL and SWR) were shown to be able to reject worms within just 8 weeks of inoculation with infective larvae (Wahid et al. 1989). Both strains have been known for some time to be closely related (Rice and O'Brien, 1980), and this has been confirmed recently by SNP-based analyses. They form a tight clade with various other strains not yet assessed for resistance to H. bakeri (Tsang et al. 2005; Sakai et al. 2005). However, despite their close ancestry, SJL and SWR mice differ in one fundamental aspect of their response to intestinal nematodes: SWR produce the classic mastocystosis, but SJL mice do not and little, if any, parasite-specific IgE (Mitchell et al. 1982; Watanabe et al. 1993; Ben-Smith et al. 2003). Therefore, if the mast cell and $\mathrm{IgE}$ responses are one mechanism for expulsion of adult worms, clearly SJL accomplish this by an alternative effector mechanism, possibly through an intense nitric-oxide response in the gut mucosa as suggested by BenSmith et al. (2003).

Behnke and Parish (1979b) had argued that expression of host-protective immunity to $H$. bakeri was dependent first on the development of resistance to the immunomodulatory factors secreted by the worms, in this case by neutralizing antibodies. However, strains may vary in their capacity to develop such antibodies, and therefore variation in the ability to reject adult worms may be explained by genetic differences in mouse strains in their susceptibility/resistance to immunomodulation. Evidence for this hypothesis was provided by Robinson et al. (1988) and by Pleass and Bianco (1994), who showed that adult worms were unable to ablate the development of resistance in the strong-responder mouse strains such as NIH and SJL, but did so readily in the weaker-responding CFLP and CBA mice.

It became evident in the 1980-90s that mouse strains expressing the H-2q (SWR and NIH), H-2s (SJL) and H-2f (B10.M) MHC haplotype were generally more resistant than other strains (Behnke and Robinson, 1985; Enriquez et al. 1988a), and hence, consistent with other metazoan parasites and with experiments in bacterial and protozoan pathogens, a role for MHC-linked genes was suggested (Wakelin and Blackwell, 1988; Enriquez et al. $1988 a$; Behnke and Wahid, 1991). MHC-congenic strains then came into their own, and the central role of the MHC in regulating infections with species such as Trichinella spiralis and Trichuris muris was established (Wassom et al. 1983; Else and Wakelin, 1988; Else et al. 1990; Wassom and Kelly, 1990). For those fortunate enough to have access to MHCrecombinant strains, it became possible to dissect out some of the loci within the MHC that played a crucial role. In this way Enriquez et al. (1988a), building on Wassom's earlier work with Trichinella spiralis (Wassom et al. 1984) and exploiting Chella David's MHC-recombinant strains, were able to show that at least two sets of genes in the MHC region of the mouse played a dominant role in controlling resistance. One of these mapped near the MHC Class II $\mathrm{E}$ alpha locus, and the other was a locus further downstream, towards the D-end of the MHC of the mouse. Unlike other American workers of the time, Wassom and his collaborators referred to the parasite as $N$. dubius. Most other American laboratories, in contrast to British and Australian laboratories, had by this time converted to using the name $H$. polygyrus.

Through breeding experiments it was found that the capacity to expel worms and to resist secondary infections was inherited in a dominant manner (Behnke and Robinson, 1985; Brindley et al. 1986; Enriquez et al. 1988c). Crosses of fast-responder strains such as SWR and SJL with slow-responder strains, always produced fast-responding F1 hybrids (Wahid et al. 1989). Moreover, when SWR and SJL mice were crossed the resulting progeny were even better at removing worms, eliminating primary infections within 4 weeks of inoculation with larvae, compared with 8 weeks in either parental strain (Wahid and Behnke, 1993). Undoubtedly hybrid vigour, heterosis, and gene complementation were features of this system.

In the last 2 decades, researchers switched to exploiting knockout mice or transgenic strains with up-regulated genes, in order to dissect out the components of the processes that lead to resistance (Else and Finkelman, 1998; Gause et al. 2003; Anthony et al. 2006). Informative as these approaches are, and they have made an enormous contribution to our understanding of the immunological processes that result in resistance to $H$. bakeri and other nematodes, 
they do not shed light on natural variation in resistance. The latter is dependent not on absence and probably not on duplication of genes (although variation in copy number is perfectly normal in a natural population), but rather mostly on the possession of combinations of alleles that lead to strong immunity, or to a much weaker response and possibly long-term tolerance of infection.

If we are to understand how to improve breeds of livestock, to make them naturally resistant to worm infections, then knowledge of where natural allelic variation in genes lies is essential. Once these genes have been identified, genetic markers flanking relevant loci can be developed and used to increase the precision and efficiency of conventional breeding programmes aiming to develop genetically resistant breeds. That is the major reason for pursuing the chase to identify the genes involved (Behnke et al. 2003).

MOLECULAR MARKERS ASSIST THE SEARCH FOR QUANTITATIVE TRAIT LOCI (QTL)

In the meantime, new tools were being developed to facilitate the identification of chromosomal regions where genes responsible for traits of interest are located. Molecular genetics had moved on at a rapid pace, and mouse geneticists had developed so-called microsatellite markers for the entire mouse genome (Dietrich et al. 1992; Rhodes et al. 1998; Silver, 1995, 2008). Microsatellites are short tandem repeats of DNA sequences, which have been shown to be randomly distributed throughout eukaryotic genomes. They are usually non-coding and therefore neutral to selection, and because of the repetitive nature of the short DNA sequences constituting microsatellites, they are highly polymorphic (have variable length of sequences) among different individuals in any one given population. By 1996, over 6000 markers had been developed, spanning all the murine chromosomes and facilitating a dense genetic linkage map of the entire mouse genome (Dietrich et al. 1996). The polymerase chain reaction (PCR), another key technical invention, facilitated the use of microsatellites in genotyping polymorphisms at specific microsatellite loci. PCR primers, flanking each microsatellite locus, are designed such that they will only amplify a small piece of DNA at specific and known chromosomal regions (Silver, 1995, 2008), allowing microsatellites to be used in genetic analysis as single-copy genes. Microsatellites typically have 5-10 different length variants (alleles) in a population, making it easy to find markers that are informative in genotyping progeny derived from different parental strains or even individuals in an outbred population. The mouse genome informatics database at the Jackson Laboratory lists the size of PCR products obtained from each microsatellite locus for many mouse strains (http://www.informatics.jax.org/genes.shtml). This information can be used to identify microsatellite loci that have differences in the number of repeats between the strains of mice being investigated. The differences in numbers of repeats mean that there are differences in length of the PCR products, and these can be easily detected by polyacrylamide gel electrophoresis or on capillary sequencers.

The introduction of microsatellite genotyping dramatically simplified genetic mapping and lowered the cost. This in turn led to an explosion in mapping studies for which the inbred mouse strains of known phenotype make ideal founders. In a mapping study, 2 inbred lines of mice that differ in the phenotype of interest are mated to create an F1 population. Since their parents were inbred with pairs of identical chromosomes, the F1 are also all genetically almost identical to each other. The F1 are inter-crossed to create 100-1000 F2 mice that are then scored for the phenotype of interest and also genotyped with around 100-200 polymorphic microsatellite markers, pre-selected to cover virtually all the mouse genome. The phenotype and genotype data generated in this way are analysed using programmes that generate linkage maps and calculate the mean value of the phenotype for each genotype at each locus. Where the mean of the phenotype differs significantly between genotypes, then this constitutes evidence for a nearby gene that regulates the phenotype.

The power of this technology is enormous. It was used to define the QTL of the genes controlling trypanotolerance in mice (Iraqi et al. 2000; Kemp et al. 1997), and then the genes that control resistance to H. bakeri (Iraqi et al. 2003; Menge et al. 2003; Behnke et al. 2006a) and resistance to malaria (Hernandez-Valladares et al. 2004). The key advantage of this approach was that for the first time it allowed us to identify chromosomal regions involved in resistance outside the MHC. Much of the earlier work had indicated that important genes with a major influence on the resistance status of their hosts lie outside the MHC, but virtually all earlier work had been focused on the MHC because this was the only region for which panels of congenic and recombinant strains of mice were available.

In the first study of this type with a gastrointestinal nematode, Iraqi et al. (2003) exploited the slowresponder strain CBA and the rapid-responder SWR mice. The literature on resistance to $H$. bakeri records many different immunizing protocols developed by various research groups in an attempt to induce some measurable immunity in mice (van Zandt, 1961; Jones and Rubin, 1974; Cypess and Zidian, 1975). For this work, we wanted to use a protocol that would go some way to mimicking the natural acquisition of larvae over time by grazing animals. Informed by earlier studies using repeated and trickle infections (Bartlett and Ball, 1974; Mitchell and Prowse, 1979; Prowse et al. 1979; 
Brailsford and Behnke, 1992), in addition to some additional initial exploratory pilot work, we compromised on a protocol in which each mouse was given 125 infective larvae once a week for 6 weeks, 7 exposures to larvae in total (Behnke et al. 2003).

It was necessary first to characterize both the parasitological and immunological events associated with this type of exposure. As expected, worm burdens accumulated in the poor-responder CBA mice, building up from one week to the next, so that by the sixth week the average worm burden was in excess of 300 , some animals harbouring 500 and more worms (Behnke et al. 2003). In contrast, SWR mice regulated their worm burdens, so that fewer intestinal adult worms were detectable as early as 14 days after the start of this repeated inoculation procedure, and by the fifth and sixth weeks there were virtually no more adult worms resident in the gut, despite continued exposure to infective larvae. SWR mice became solidly immune to this immunizing protocol, whereas CBA mice were still highly susceptible in the sixth week.

In the initial project we assessed QTL in F2 hybrids and were able to detect 7 QTL on chromosomes 1, 2, 8, 13, 17 and 19 linked with resistance traits. The combined additive effect of the $5 \mathrm{QTL}$ for worm survival accounted for about $60 \%$ of the difference in worm burdens between the 2 parental lines. The dominance effects of these 5 QTL were all in the direction of resistance, supporting the earlier work that had already shown that the resistant trait was dominant. It was also reassuring to find that there was a highly significant QTL on chromosome 17 , mapping to a chromosomal region encompassing the MHC of the mouse.

In a subsequent study (Behnke et al. 2006a), exploiting the advanced intercross strategy of Darvasi and Soller (1992), we went on to generate over 1000 F6/7 crosses between these 2 strains, in an effort to pin down more precisely the loci underpinning the QTL and hence to identify the genes responsible. We were able to demonstrate clearly that the QTL on chromosome 17 plays a prominent role in resistance, and we found confirmation of the major QTL on chromosome 1. Interestingly, a QTL for resistance to the intestinal adult phase of $T$. spiralis has also been detected on the homologous chromosome of the rat, chromosome 9 (Suzuki et al. 2006). If this QTL proves to be attributable to exactly the same gene/s as those underlying the QTL for resistance to H. bakeri, important genes controlling resistance to 2 quite distantly related intestinal nematodes will have been discovered.

Whilst the high-resolution mapping lent further support for genes mapping within the MHC, with considerably narrower confidence limits, we were less successful in fine-mapping the QTL on chromosome 1. This QTL was highly significant, but its confidence limits were still relatively broad, encompassing a relatively large section of chromosome 1 in a region known to be relatively gene poor. Others have also found difficulties in dissecting a similar region on chromosome 1 , where recombination cold spots are known (Hill et al. 2000; Wicker et al. 2004). Mapping genes in the $\mathrm{F} 2$ as outlined above is a fairly crude approach that typically discovers a region of $30-60 \mathrm{Mb}$ in size, which can contain thousands of genes. In order to narrow this region down it is necessary to phenotype and genotype many more mice with recombinations within the QTL region. This can usually be achieved by inter-crossing or back-crossing the mice for several more generations, as described above for the F6 study. The mean recombination rate in mice is about 0.76 per $100 \mathrm{Mb}$ (Broman et al. 2002); however, if the recombination rate in a particular region is lower than average, a recombination cold spot, then it will be necessary to phenotype and genotype many more mice in order to refine the QTL position than in a recombination hot spot.

Throughout all this work, during both the F2 and the F6/7 study, we also monitored various immunological parameters that might reflect potential effectors of resistance. Because of the nature of these experiments, and in particular because of the priority given to parasite-resistance traits, it was not possible to obtain cells and serum during the early phase of the infection, at a time when the immunological events that would lead to worm expulsion were being generated. Based on our exploratory data (Behnke et al. 2003), we took a small blood sample from the tail of each mouse in the third week. The rest had to wait until the animals were culled in the sixth week, by which time some mice may have been without worms for up to 2 weeks. It is only at this time that individual mice could be phenotyped for resistance to the parasite. The priority for the blood sample was to measure the plasma levels of $\mathrm{mMCP}-1$, the mastcell enzyme reflecting mast-cell activation in the mucosa, and believed to show a strong correlation with worm expulsion (Wahid et al. 1994). We have moved a long way since then, and now using multiplex systems and real-time PCR it is possible to measure many different cytokines in a very small volume of blood. Our pilot data had revealed that SWR mice mounted a potent mast-cell response, also reflected in very high plasma levels of mMCP-1 almost from the start of the immunizing protocol, but peaking in weeks 3 and 4 before subsiding to background levels by the sixth week (Behnke et al. 2003). We were reluctant to take larger volumes of blood in case the stress and trauma during this critical period impaired the capacity of mice to respond, with knock-on effects for worm expulsion and our genetic analysis. The immunological traits quantified were the $\mathrm{mMCP}-1$ response in week $3, \mathrm{IgG} 1$ response to adult worm and L4 antigens, IgE response to L4 antigens, the granulomatous response, and (in the 
F6/7 study) the packed cell volume in weeks 3 and 6 . Interestingly, we found that several of these traits ( $\mathrm{IgG} 1$ and $\mathrm{IgE}$ responses, granulomatous response and $\mathrm{mMCP}-1$ ) showed significant QTL in the same region of chromosome 17 as the parasite resistance traits, consistent with the idea that the genes involved here are those concerned with initial antigen processing and presentation, since these are crucial to all types of responses. Disappointingly, however, no trait generated strong QTL coinciding with any of the parasite resistance traits on any other chromosomes in the F2 study. There was a QTL for IgG1 to adult worm and L4 antigens on chromosome 1 in the F6/7 study, but the LOD scores were low and the confidence intervals for the response to L4 antigens were very broad. Thus from among the range of possible immune effectors that we had measured, each chosen on the basis of earlier studies indicating correlation with resistance, none were convincingly supported by the QTL analysis.

The great attraction of QTL studies is that they are 'hypothesis free'; they do not make any prior assumption about what sort of genes are involved: in addition, they identify loci that regulate the difference in phenotype. The well-known components of the immune response to $H$. bakeri are undoubtedly important for controlling the disease, but the mapping studies show that the difference in response of different mouse strains is not due to differences in these immunological pathways. The genes that cause the differences are still to be discovered, but they may be in the innate immune-response system initiated early in the course of infection. The success of this early response is likely to have important knock-on effects on the adaptive immune response to the parasites, and this will be reflected as differences in the classical immune-response pathways of strains varying in response phenotype. Consequently, these immune pathway differences will be correlated with the response to the infection, but as the QTL studies show, their differences are not causing the differences in response to the infection.

\section{WHAT NEXT?}

The QTL studies summarized above represent a major advance in our understanding of the genes that underpin the resistance status of mice to $H$. bakeri. For the first time we now have unambiguous evidence that genes located outside the MHC play a key role in resistance, and we have some idea about their chromosomal locations. This is important: breeding livestock for uniformity in MHC genes would not be a wise move, since MHC haplotypes known to confer on animals resistance to helminths are often associated with susceptibility to protozoan infections (Wakelin and Blackwell, 1988). Thus the maintenance of MHC diversity, and some argue heterozygosity, is seen as important in preserving broad-spectrum resistance in flocks/herds of livestock and wild animals (Penn et al. 2002; Wegner et al. 2003; Stear et al. 2005; Oliver et al. 2009).

The mechanisms of resistance to intracellular protozoa and extracellular metazoan parasites are so different that it becomes feasible to breed for alleles at loci which make animals resistant to GI nematodes, but have no cost in terms of enhanced susceptibility to other parasites. The task is now to find those genes and to define the alleles that donate resistance without penalties.

Another possibility is that resistant animals might be producing as yet unidentified 'novel' molecules with direct anti-nematode toxic effects, as products of genes yet to be identified. The identification of such genes and their products could open new vistas to a new generation of therapeutic agents both in livestock and humans. This possibility may not be far-fetched given that the vast majority of genes have unknown functions, and the fact that many useful drugs have been developed from soil fungi.

It has become routine to identify QTL that regulate a wide range of phenotypes, but it has proved far more difficult to identify the causative genes. Over 2000 QTL have been mapped in mice and rats, but fewer than $1 \%$ of these have been characterized at the molecular level (Flint et al. 2005 ; Peters et al. 2007). One strategy for identifying the quantitative trait genes is to employ gene arrays to determine which of the genes in the QTL region show the strongest expression during the infection protocols used for the QTL analysis and/or differences in expression between strains. This would be far more economical than examining genes throughout the genome by this technology (Diez-Tascón et al. 2005). The strategy is based on the reasonable premise that since there are far more polymorphisms in non-coding regions than in coding regions, differences in expression are likely to be more common than polymorphisms in aminoacid sequences. Nevertheless, the large numbers of genes with expression responses in most QTL regions, and the uncertainty about which tissues or cells or time-points to assay, has meant that this strategy has not fulfilled its initial promise, although it can still provide valuable pointers to candidate genes (Fisher et al. 2007).

Several additional genetic strategies are available for locating more precisely the loci within the QTL. The transfer of resistance QTL from a resistant to a susceptible mouse strain has already been demonstrated in the case of trypanosomiasis (Koudandé et al. 2005). In an amazing combination of markerassisted backcross breeding strategies, Koudandé et al. (2005) achieved precisely this in murine trypanosomiasis. Each of 3 QTL was transferred from the resistant $\mathrm{C} 57 \mathrm{BL} / 6$ mouse strain to the susceptible A/J strain, either alone or in combination with others. They were able to evaluate the relative contribution of the genes underpinning each of the 
3 QTL in isolation and in combination with others. Perhaps unexpectedly they found that some of their backcross lines were not viable, presumably because of recombinations that gave rise to deleterious combinations of alleles. However, the feasibility of the approach of marker-assisted introgression of disease resistance was confirmed. But even so, it is not clear whether introgression of disease-resistance genes into productive but susceptible livestock will lead to reductions in economic value due to the mechanisms involved in disease resistance (Colditz, 2004). Optimistically this will not be a problem, since the prevailing view, based on selection for resistance in livestock, is that production traits do not suffer as a consequence (Bisset et al. 1997; Bishop and Stear, 2003), although to some extent this is still an open question because there is evidence to the contrary in some livestock systems (McEwan et al. 1995 ; Zaralis et al. 2008). Nevertheless strategies for reconciling this conflict between disease resistance and production traits have been suggested (Bishop and Morris, 2007).

A further approach would be to generate a range of mouse strains on a susceptible background, but each carrying only a small section of the QTL. Indeed such an approach has already been utilized in trypanosomiasis and malaria (Foote et al. 2005), and by immunologists dissecting the NOD mutation on chromosome 1 of the mouse (Wicker et al. 2004). This does require considerable investment in time and cost, because breeding these strains of mice is neither quick nor cheap, and is not easily supported by conventional 3 -year research projects. It requires confidence and long-term investment.

With the completion of the mouse genome project, a range of new tools is becoming available for mouse geneticists, some in the short-term, others in years to come. An initiative funded by the Wellcome Trust set out to create a panel of 100 recombinant mouse lines (Collaborative Cross genetic reference panel), available in 2012 (Iraqi et al. 2008). Other initiatives in the USA, funded by the US Department of Energy, the Ellison Foundation and the National Institutes of Health of the USA, are aiming to produce an additional $300+$ lines. These strains will allow fine mapping of QTL and identification of their underlying genes with unprecedented precision.

The publication of 8 million murine singlenucleotide polymorphisms has now created a remarkable resource for high-resolution genotyping which will almost certainly supersede microsatellites (Frazer et al. 2007). The NIH has funded the discovery of 8 million SNP in 15 inbred strains of mice and the data show that there are only $3-4$ unique haplotypes at any given position (Frazer et al. 2007). The Wellcome Trust is funding the complete sequencing of 15 mouse strains. In order to exploit this information, we recently compared the resistance status of a panel of 8 additional strains to the same protocol used for the QTL project (Behnke et al. $2006 b$ ). Much as expected from earlier work using different immunizing protcols, $\mathrm{A} / \mathrm{J}, \mathrm{C} 57 \mathrm{BL} / 6, \mathrm{C} 3 \mathrm{H}$ and CBA mice all tolerated intense infections and were unable to clear worm burdens within the 6week experimental period. Again as expected, SWR, SJL and NIH were all highly resistant to infection. Three strains gave equivocal results. These were DBA/2, 129/J and BALB/c mice, which performed inconsistently between the two laboratories in which these experiments were undertaken, and in some experiments showed evidence of resistance, whilst in others did not. Since the extensive haplotype data are now available for most of these strains, it will be possible to identify the parts of the QTL region where the resistant strains share ancestral haplotypes and susceptible strains have different haplotypes. This should substantially reduce the number of candidate genes.

It has been asked whether model organisms are still necessary now that it is possible to genotype $500000 \mathrm{SNP}$ in humans at reasonable cost (Hunter and Crawford, 2008). Using these large SNP panels it is possible to undertake whole-genome association studies, and these have lead directly to the discovery of more human quantitative trait genes in the last two years than in the previous 20 (The Wellcome Trust Case Control Consortium, 2007). Similar-sized SNP panels will be available for some livestock species within the next couple of years. These might make it possible to discover loci regulating a wide range of disease traits in farm animals as well as humans. However, several thousand samples will need to be tested, and they will need to come from a panmictic population that varies significantly in the phenotype of interest. For many disease resistance traits in livestock there is limited variability within breeds, and most variability is between breeds. In humans there is a similar problem with ethnic stratification of populations. This means that the whole-genome association strategy may have limited utility for helminth infections, particularly given the large human and livestock diversity across their ranges. In any event the identification and phenotyping of such large numbers of subjects is difficult and expensive. Furthermore, the risk of developing disease that has been associated with genes discovered in wholegenome association studies has been small (The Wellcome Trust Case Control Consortium, 2007). Thus it is unclear whether the rewards from this strategy will repay the costs.

Consortia from Europe, Canada and the USA are currently creating knockouts of every known gene in mice (Anonymous, 2007). This resource will significantly reduce the cost and difficulty associated with testing hypotheses that emerge from mapping studies. However, as was pointed out earlier, knockout mice can only show that a gene is in a pathway involved in a phenotype; they cannot show 
that an allelic variant of that gene is causing the observed difference in phenotype between 2 strains. For the latter, transgenic replacements of the individual alleles are necessary: this may also be an informative route to follow.

A range of large-scale resources are rapidly becoming available for mouse and livestock genetics almost unimaginable 10 years ago, but none will provide an instant answer to the problems of discovering genes that cause differences in phenotype (Hunter and Crawford, 2008). They do, however, collectively make it possible to undertake projects that were formerly almost impossible. But finding the QTL genes is likely to continue to require collaborations between epidemiologists, geneticists, immunologists and cell biologists, and in the context of parasitic infections, parasitologists, and also considerable patience and resources.

The technologies that we employ in this field have changed so rapidly that young scientists these days often seem unaware of the core background work that was conducted earlier, and how it laid the foundations of the knowledge base that they now explore with the more refined and considerably more powerful techniques available at their disposal. Electronic databases have made literature surveys so much easier, but equally they have seemingly impeded the citation of the older studies not indexed electronically, and not yet available as easily downloadable PDFs. Electronic retrieval is so much easier than the effort required to trace paper copies of older studies, sitting buried and rarely consulted in library repositories, and this is likely to be an even greater problem as we move more and more towards open access publishing. There is pressure to cite last week's publications and nothing older than 2 years, and we seem to have all but forgotten significant contributions published a decade or more ago.

\section{CONCLUDING REMARKS}

In this article, we have emphasized that $H$. bakeri is a wonderful model of chronic intestinal nematode infections, and we hope to have inspired the reader to exploit this model in future projects. It is now the first mouse nematode for which resistance QTL have been described and mapped with high resolution. With the aid of modern molecular tools, the next decade will inevitably see these honed to the gene level. Already there are signs that the strongest QTL (mouse chromosome 1) are not specific to H. bakeri, and therefore it will be worth exploiting comparative mapping methods to assess their relevance to resistance in livestock and humans. In this context the proximal section of mouse chromosome 1 is syntenic with parts of sheep chromosome 2, and Davies et al. (2006) reported a QTL that affects faecal egg counts in the autumn in Scottish Blackface lambs on this chromosome (although earlier studies had failed to find QTL for resistance in sheep on this chromosome: Beh et al. 2002; Dominik, 2005). Genetic studies require long-term investment, but the fruits at the end of the road are worth pursuing. As we see anthelmintic drug resistance proliferating around the globe, without any convincing signs that new drugs will become available soon to control intestinal nematodes, genetic resistance will be an even more important road to follow in the years to come.

In our final comments we reiterate again that, while pushing ahead our understanding of this model system, exploiting the ever more powerful technologies now at our disposal, we should not lose sight of the history of this parasite (in particular the problems caused by the changes in nomenclature) and build on what is already known about its host/parasite relationship. There is a wealth of information on the biology of Nematospiroides dubius and H.polygyrus in the public domain, so let us be aware of this as we explore H. bakeri in even more detail.

We thank the Wellcome Trust for funding the QTL analyses, and the MRC for funding genetic studies on $H$. bakeri. The inspiration and guidance of Derek Wakelin is much appreciated. I (J.M.B.) would like to thank especially the many $\mathrm{Ph} . \mathrm{D}$. students, post-docs, colleagues and visitors that have worked in my laboratories, and whose contributions, inspiration, debate, advice and friendship have made research in this field such a pleasure over the last 38 years. We thank also Derek Wakelin, Jan Bradley, Phil Harris, Kathryn Else, Mike Doenhoff, Richard Pleass and Francis Gilbert for their comments on earlier drafts of this paper. Jill Brown and Ann Lowe provided technical assistance for which we are most grateful.

\section{REFERENCES}

Abu-Madi, M. A., Mohd-Zain, S. N., Lewis, J. W. and Reid, A. P. (2000). Genomic variability within laboratory and wild isolates of the trichostrongyle mouse nematode Heligmosomoides polygyrus. Fournal of Helminthology 74, 195-201.

Abu-Madi, M. A., Pleass, R. J. and Lewis, J. W. (1994). Metabolic labelling of wild and laboratory subspecies of the trichostrongyle nematode Heligmosomoides polygyrus. Veterinary Parasitology 55, 235-243.

Ackert, J. E., Eisenbrandt, L. L., Wilmoth, J. H., Glading, B. and Pratt, I. (1935). Comparative resistance of five breeds of chickens to the nematode Ascaridia lineata (Schneider). Fournal of Agricultural Research 50, 607-624.

Ali, N. M. H. and Behnke, J. M. (1983). Nematospiroides dubius: factors affecting the primary response to SRBC in infected mice. Fournal of Helminthology 57, 343-353.

Ali, N. M. H. and Behnke, J. M. (1984). Non-specific immunodepression by larval and adult Nematospiroides dubius. Parasitology 8, 153-162.

Anonymous (2007). A mouse for all reasons. Cell 128, 9-13.

Anthony, R. M., Urban, J. F., Jr., Alem, F., Hamed, H. A., Rozo, C. T., Boucher, J.-L., Rooijen, N. V. and Gause, W. C. (2006). Memory Th2 cells induce 
alternatively activated macrophages to mediate protection against nematode parasites. Nature Medicine 12, 955-960.

Asakawa, M. (1988). Genus Heligmosmoides Hall, 1916 (Heligmosomidae: Nematoda) from the Japanese wood mice, Apodemus spp. II. A review of the genus Heligmosomoides with the establishment of the phylogenetic lines of known species. Fournal of the College of Dairying 12, 349-365.

Baker, N. F. (1954). Trichostrongylidosis - the mouse as an experimental animal. Proceedings of the American Veterinary Medical Association 91, 185-191.

Bancroft, A. J., Else, K. J. and Grencis, R. K. (1994). Low-level infection with Trichuris muris significantly affects the polarization of the CD4 response. European Fournal of Immunology 24, 3113-3118.

Bansemir, A. D. and Sukhdeo, M. V. K. (1994). The food resource of adult Heligmosomoides polygyrus in the small intestine. Fournal of Parasitology 80, 24-28.

Bansemir, A. D. and Sukhdeo, M. V. K. (1996). Villus length influences habitat selection by Heligmosomoides polygyrus. Parasitology 113, 311-316.

Bartlett, A. and Ball, P. A. J. (1972). Nematospiroides dubius in the mouse as a possible model of endemic human hookworm infection. Annals of Tropical Medicine and Parasitology 66, 129-134.

Bartlett, A. and Ball, P. A. J. (1974). The immune response of the mouse to larvae and adults of Nematospiroides dubius. International Fournal for Parasitology 4, 463-470.

Baylis, H. A. (1926). On a trichostrongylid nematode from the wood mouse (Apodemus sylvaticus). Annals and Magazine of Natural History 18, 455-464.

Baylis, H. A. (1927). A further note on Nematospiroides dubius Baylis 1926. Annals and Magazine of Natural History 20, 102-105.

Beh, K. J., Hulme, D. J., Callaghan, M. J., Leish, Z., Lenane, I., Windon, R. G. and Maddox, J. F. (2002). A genome scan for quantitative trait loci affecting resistance to Trichostrongylus colubriformis in sheep. Animal Genetics 33, 97-106.

Behnke, J. M. (1987). Evasion of immunity by nematode parasites causing chronic infections. Advances in Parasitology 26, 1-71.

Behnke, J. M., Bajer, A., Sinski, E. and Wakelin, D. (2001). Interactions involving intestinal nematodes of rodents: experimental and field studies. Parasitology 122, S39-S49.

Behnke, J. M., Barnard, C. J. and Wakelin, D. (1992). Understanding chronic nematode infections: evolutionary considerations, current hypotheses and the way forward. International Fournal for Parasitology Invited review 22, 861-907.

Behnke, J. M., Cabaj, W. and Wakelin, D. (1992). Susceptibility of adult Heligmosomoides polygyrus to intestinal inflammatory responses induced by heterologous infection. International Fournal for Parasitology 22, 75-86.

Behnke, J. M., Hannah, J. and Pritchard, D. I. (1983). Nematospiroides dubius in the mouse: evidence that adult worms depress the expression of homologous immunity. Parasite Immunology 5, 397-408.
Behnke, J. M., Keymer, A. E. and Lewis, J. W. (1991). Heligmosomoides polygyrus or Nematospiroides dubius? Parasitology Today 7, 177-179.

Behnke, J. M., Iraqi, F., Menge, D., Baker, L., Gibson, J. and Wakelin, D. (2003). Chasing the genes that control resistance to gastrointestinal nematodes. Fournal of Helminthology 77, 99-109.

Behnke, J. M., Iraqi, F. A., Mugambi, J. M., Clifford, S., Nagda, S., Wakelin, D., Kemp, S. J., Baker, R. L. and Gibson, J. P. (2006a). High resolution mapping of chromosomal regions controlling resistance to gastro-intestinal nematode infections in an advanced intercross line of mice. Mammalian Genome 17, 584-597.

Behnke, J. M., Lowe, A., Clifford, S. and Wakelin, D. (2003). Cellular and serological responses in resistant and susceptible mice exposed to repeated infection with Heligmosomoides polygyrys bakeri. Parasite Immunology 25, 333-340.

Behnke, J. M., Mugambi, J. M., Clifford, S., Iraqi, F., Baker, R. L., Gibson, J. P. and Wakelin, D. (2006 b). Genetic variation in resistance to repeated infections with Heligmosomoides polygyrus bakeri, in inbred mouse strains selected for the Mouse Genome Project. Parasite Immunology 28, 85-94.

Behnke, J. M. and Parish, H. A. (1979a). Nematospiroides dubius: Arrested development of larvae in immune mice. Experimental Parasitology 47, 116-127.

Behnke, J. M. and Parish, H. A. (1979b). Expulsion of Nematospiroides dubius from the intestine of mice treated with immune serum. Parasite Immunology 1, 31-26.

Behnke, J. M. and Robinson, M. (1985). Genetic control of immunity to Nematospiroides dubius: a 9-day anthelmintic abbreviated immunizing regime which separates weak and strong responder strains of mice. Parasite Immunology 7, 235-253.

Behnke, J. M. and Wahid, F. N. (1991). Immunological relationships during primary infection with Heligmosomoides polygyrus (Nematospiroides dubius) : H-2 genes determine worm survival. Parasitology 103, 157-164.

Behnke, J. M. and Wakelin, D. (1973). The survival of Trichuris muris in wild populations of its natural hosts. Parasitology 67, 157-164.

Behnke, J. M. and Wakelin, D. (1977). Nematospiroides dubius: stimulation of acquired immunity in inbred strains of mice. Fournal of Helminthology 51, 167-176.

Behnke, J. M., Williams, D. J., Hannah, J. and Pritchard, D. I. (1987). Immunological relationships during primary infection with Heligmosomoides polygyrus (Nematospiroides dubius): the capacity of adult worms to survive following transplantation to recipient mice. Parasitology 95, 569-581.

Ben-Smith, A., Lammas, D. A. and Behnke, J. M. (2003). The relative involvement of Th1 and Th2 associated immune responses in the expulsion of a primary infection of Heligmosomoides polygyrus in mice of differing response phenotype. Fournal of Helminthology 77, 133-146.

Bishop, S. C. and Morris, C. A. (2007). Genetics of disease resistance in sheep and goats. Small Ruminant Research 70, 48-59. 
Bishop, S. C. and Stear, M. J. (2003). Modelling of host genetics and resistance to infectious diseases: understanding and controlling nematode infections. Veterinary Parasitology 115, 147-166.

Bisset, S. A., Vlassoff, A., West, C. J. and Morrison, L. (1997). Epidemiology of nematodosis in Romney lambs selectively bred for resistance or susceptibility to nematode infection. Veterinary Parasitology 70, 255-269.

Brailsford, T. J. and Behnke, J. M. (1992). The dynamics of trickle infections with Heligmosomoides polygyrus in syngeneic strains of mice. International Fournal for Parasitology 22, 351-359.

Brindley, P. J. and Dobson, C. (1982). Nematospiroides dubius in mice selected for liability to infection: modification of parasite biology through host selection. International Fournal for Parasitology 12, 573-578.

Brindley, P. J., He, S., Sitepu, P., Pattie, W. A. and Dobson, C. (1986). Inheritance of immunity in mice to challenge infection with Nematospiroides polygyrus. Heredity 57, 53-58.

Broman, K. W., Rowe, L. B., Churchill, G. A. and Paigen, K. (2002). Crossover interference in the mouse. Genetics 160, 1123-1131.

Bryant, V. (1973). The life cycle of Nematospiroides dubius, Baylis, 1926 (Nematoda: Heligmosomidae). Fournal of Helminthology 47, 263-268.

Cable, J., Harris, P. D., Lewis, J. W. and Behnke, J. M. (2006). Molecular evidence that Heligmosomoides polygyrus from laboratory mice and wood mice are separate species. Parasitology 133, 111-122.

Chehresa, A., Beech, R. N. and Scott, M. E. (1997). Life-history variation among lines isolated from a laboratory population of Heligmosomoides polygyrus bakeri. International Fournal for Parasitology 27, 541-551.

Colditz, G. I. (2004). Some mechanisms regulating nutrient utilization in livestock during immune activation: An overview. Australian fournal of Experimental Agriculture 44, 453-457.

Colwell, D. A. and Wescott, R. B. (1973). Prolongation of egg production of Nippostrongylus brasiliensis in mice concurrently infected with Nematospiroides dubius. Fournal of Parasitology 59, 216.

Courtney, C. H. and Forrester, D. J. (1973). Interspecific interaction between Hymenolepis microstoma (Cestoda) and Heligmosomoides polygyrus (Nematoda) in mice. Fournal of Parasitology 59, 480-483.

Crandall, R. B., Crandall, C. A. and Franco, J. A. (1974). Heligmosomoides polygyrus $(=$ Nematospiroides dubius): humoral and intestinal immunologic responses to infection in mice. Experimental Parasitology 35, 275-287.

Crawford, C., Behnke, J. M. and Pritchard, D. I. (1989). Suppression of heterologous immunity by Nematospiroides dubius antigens in vitro. International Fournal for Parasitology 19, 29-34.

Cypess, R. H., Lucia, H. L., Dunsford, H. A. and Enriquez, F. J. (1988). The tissue reactions of mice to infection with Heligmosomoides polygyrus. Fournal of Helminthology 62, 69-76.

Cypess, R. H., Lucia, H. L., Zidian, J. L. and Rivera-Ortiz, C. I. (1977). Heligmosomoides polygyrus: temporal, spatial and morphological population characteristics in LAF1/J mice. Experimental Parasitology 42, 34-43.

Cypess, R. H. and Zidian, J. L. (1975). Heligmosomoides polygyrus (=Nematospiroides dubius): the development of self-cure and/or protection in several strains of mice. Fournal of Parasitology 61, 819-824.

Darvasi, A. and Soller, M. (1992). Selective genotyping for determination of linkage between a molecular marker and a quantitative trait locus. Theoretical and Applied Genetics 85, 353-359.

Davies, G., Stear, M. J., Benothman, M., Abuagob, O., Kerr, A., Mitchell, S. and Bishop, S. C. (2006). Quantitative trait loci associated with parasitic infection in Scottish blackface sheep. Heredity 96, 252-258.

Day, K. P., Howard, J. R., Prowse, S. J., Chapman, C. B. and Mitchell, G. F. (1979). Studies on chronic versus transient intestinal nematode infections in mice. I. A comparison of responses to excretory/secretory (ES) products of Nippostrongylus brasiliensis and Nematospiroides dubius worms. Parasite Immunology 1, 217-239

Dehlawi, M. S., Wakelin, D. and Behnke, J. M. (1987). Suppression of mucosal mastocytosis by infection with the intestinal nematode Nematospiroides dubius. Parasite Immunology 9, 187-194.

Dehlawi, M. S. and Wakelin, D. (1988). Suppression of mucosal mastocytosis by Nematospiroides dubius results from an adult worm-mediated effect upon host lymphocytes. Parasite Immunology 10, 85-95.

Della Bruna, C. and Xenia, B. (1976). Nippostrongylus brasiliensis in mice: reduction of worm burden and prolonged infection induced by presence of Nematospiroides dubius. Fournal of Parasitology 62, 490-491.

Dietrich, W., Katz, H., Lincoln, S. E., Shin, H.-S., Friedman, J., Dracopoli, N. C. and Lander, E. S. (1992). A genetic map of the mouse suitable for typing intraspecific crosses. Genetics 131, 423-447.

Dietrich, W. F., Miller, J., Steen, R., Merchant, M. A., Damron-Boles, D. et al. (1996). A comprehensive genetic map of the mouse genome. Nature, London $\mathbf{3 8 0}$, 149-152.

Diez-Tascón, C., Keane, O. M., Wilson, T., Zadissa, A., Hyndman, D. L., Baird, D. B., McEwan, J. C. and Crawford, A. M. (2005). Microarray analysis of selection lines from outbred populations to identify genes involved with nematode parasite resistance in sheep. Physiological Genomics 21, 59-69.

Dobson, C. (1961). Certain aspects of the host-parasite relationship of Nematospiroides dubius (Baylis) I. Resistance of male and female mice to experimental infections. Parasitology 52, 173-179.

Dobson, C. (1982). Passive transfer of immunity with serum in mice infected with Nematospiroides dubius: influence of quality and quantity of immune serum. International Fournal for Parasitology 12, 207-213.

Dobson, C., Sitepu, P. and Brindley, P. J. (1985). Influence of primary infection on the population dynamics of Nematospiroides dubius after challenge infections in mice. International Fournal for Parasitology 15, 353-359. 
Dobson, C. and Tang, J. (1991). Genetic variation and host-parasite relations: Nematospiroides dubius in mice. Fournal of Parasitology 77, 884-889.

Doligalska, M., Rzepecka, J., Drela, N., Donskow, K. and Gerwel-Wronka, M. (2006). The role of TGF- $\beta$ in mice infected with Heligmosomoides polygyrus. Parasite Immunology 28, 387-395.

Dominik, S. (2005). Quantitative trait loci for internal nematode resistance in sheep: a review. Genetics Selection Evolution 37 (Suppl. 1), S83-S96.

Dujardin, F. (1845). Histoire Naturelle des Helminthes ou vers Intestinaux. Librarie Encyclopédique de Roret, Paris, France.

Durette-Desset, M. C., Kinsella, J. M. and Forrester, D. J. (1972). Arguments en faveur de la double origine des nematodes nearctiques du genre Heligmosomoides HALL, 1916. Annales de Parasitologie (Paris) 47, 365-382.

Ehrenford, F. A. (1954). The cycle of Nematospiroides dubius Baylis (Nematoda: Heligmosomidae). Fournal of Parasitology 40, 480-481.

Elliott, D. E., Setiawan, T., Metwali, A., Blum, A., Urban, J. F. and Weinstock, J. V. (2004).

Heligmosomoides polygyrus inhibits established colitis in IL-10-defieient mice. European Fournal of Immunology 34, 2690-2698.

Else, K. J. and Finkelman, F. D. (1998). Intestinal nematode parasites, cytokines and effector mechanisms. International Fournal for Parasitology 28, 1145-1158.

Else, K. J. and Wakelin, D. (1988). The effects of H-2 and non-H-2 genes on the expulsion of the nematode Trichuris muris from inbred and congenic mice. Parasitology 96, 543-550.

Else, K. J., Wakelin, D., Wassom, D. L. and Klein, J. (1990). The influence of genes mapping within the major histocompatibility complex on resistance to Trichuris muris infection of mice. Parasitology 101, 61-67.

Enriquez, F. J., Brooks, B. O., Cypess, R. H., David, C. S. and Wassom, D. L. (1988a). Nematospiroides dubius: Two H-2-linked genes influence levels of resistance to infection in mice. Experimental Parasitology 67, 221-226.

Enriquez, F. J., Cypess, R. H. and Wassom, D. L. $(1988 b)$. Influence of immunizing dose and presence or absence of adult worms on the development of resistance to Nematospiroides dubius challenge infections of mice. Journal of Parasitology 74, 409-414.

Enriquez, F. J., Zidian, J. L. and Cypess, R. H. (1988c). Nematospiroides dubius: Genetic control of immunity to infections of mice. Experimental Parasitology 67, 12-19.

Fahmy, M. A. M. (1956). An investigation on the life cycle of Nematospiroides dubius (Nematoda: Heligmosomidae) with special reference to the freeliving stages. Zeitschrift für Parasitenkunde 17, 394-399.

Fakae, B. B., Harrison, L. J. and Sewell, M. M. M. (2000). The intensity and duration of primary Heligmosomoides polygyrus infection in TO mice modify acquired immunity to secondary challenge. Fournal of Helminthology 74, 225-231.

Finney, C. A., Taylor, M. D., Wilson, M. S. and Maizels, R. M. (2007). Expansion and activation of CD4(+)CD25(+) regulatory $\mathrm{T}$ cells in Heligmosomoides polygyrus infection. European Fournal of Immunology 37, 1874-1886.
Fisher, P., Hedeler, C., Wolstencroft, K., Hulme, H., Noyes, H., Kemp, S., Stevens, R. and Brass, A. (2007). A systematic strategy for large-scale analysis of genotype phenotype correlations: identification of candidate genes involved in African trypanosomiasis. Nucleic Acids Research 35, 5625-5633.

Flint, J., Valdar, W., Shifman, S. and Mott, R. (2005). Strategies for mapping and cloning quantitative trait genes in rodents. Nature Reviews Genetics 6, 271-286.

Foote, S. J., Iraqi, F. and Kemp, S. J. (2005). Controlling malaria and African trypanosomiasis: the role of the mouse. Briefings in Functional Genomics and Proteomics 4, 214-224.

Forrester, D. J. (1971). Heligmosomoides polygyrus (=Nematospiroides dubius) from wild rodents of Northern California: natural infections, host-specificity, and strain characteristics. Fournal of Parasitology 57, 498-503.

Forrester, D. J. and Neilson, J. T. McL. (1973). Comparative infectivity of Heligmosomoides polygyrus (=Nematospiroides dubius) in three species of Peromyscus. Fournal of Parasitology 59, 251-255.

Fox, J. G., Beck, P., Dangler, C. A., Whary, M. T., Wang, T. C., Shi, H. N. and Nagler-Anderson, C. (2000). Concurrent enteric helminth infection modulates inflammation and gastric immune responses and reduces Helicobacter-induced gastric atrophy. Nature Medicine 6, 536-542.

Frazer, K. A., Eskin, E., Kang, H. M., Bogue, M. A., Hinds, D. A., Beilharz, E. J., Gupta, R. V., Montgomery, J., Morenzoni, M. M., Nilsen, G. B., Pethiyagoda, C. L., Stuve, L. L., Johnson, F. M., Daly, M. J., Wade, C. M. and Cox, D. R. (2007). A sequence-based variation map of 8.27 million SNPs in inbred mouse strains. Nature, London 448, 1050-1053.

Gause, W. C., Urban, J. F., Jr. and Stadecker, M. J. (2003). The immune response to parasitic helminths: insights from murine models. Trends in Immunology 24, 269-277.

Hernandez, A. D. and Sukhdeo, M. V. (1995). Host grooming and transmission strategy of Heligmosomoides polygyrus. Fournal of Parasitology 81, 865-869.

Hernandez-Valladares, M., Naessens, J., Gibson, J. P., Musoke, A. J., Nagda, S., Rihet, P., OleMoiYoi, O. K. and Iraqi, F. A. (2004). Confirmation and dissection of QTL controlling resistance to malaria in mice. Mammalian Genome 15, 390-398.

Hill, N. J., Lyons, P. A., Armitage, N., Todd, J. A., Wicker, L. S. and Peterson, L. B. (2000). NOD Idd5 locus controls insulitis and diabetes and overlaps the orthologous CTLA4/IDDM12 and NRAMP1 loci in humans. Diabetes 49, 1744-1747.

Hunter, K. W. and Crawford, N. P. S. (2008). The future of mouse QTL mapping to diagnose disease in mice in the age of whole-genome association. Annual Reviews in Genetics 42, 131-141.

Iraqi, F. A., Behnke, J. M., Menge, D. M., Lowe, A., Teale, A. J., Gibson, J. P., Baker, L. R. and Wakelin, D. (2003). Chromosomal regions controlling resistance to gastro-intestinal nematode infections in mice. Mammalian Genome 14, 184-191.

Iraqi, F., Clapcott, S. J., Kumar, P., Haley, C. S., Kemp, S. J. and Teale, A. (2000). Fine mapping of trypanosomiasis resistance loci in murine 
advanced intercross lines. Mammalian Genome 11, 645-648.

Iraqi, F. A., Churchill, G. and Mott, R. (2008). The Collaborative Cross, developing a resource for mammalian systems genetics: a status report of the Wellcome Trust cohort. Mammalian Genome 19, 379-381.

Jenkins, D. C. and Phillipson, R. F. (1971). The kinetics of repeated low-level infections of Nippostrongylus brasiliensis in the laboratory rat. Parasitology $\mathbf{6 2}$, 457-465.

Jones, C. E. and Rubin, R. (1974). Nematospiroides dubius: mechanisms of host immunity. I. Parasite counts, histopathology and serum transfer involving orally or subcutaneously sensitized mice. Experimental Parasitology 35, 434-452.

Kemp, S. J., Iraqi, F., Darvasi, A., Soller, M. and Teale, A. J. (1997). Localization of genes controlling resistance to trypanosomiasis in mice. Nature Genetics 16, 194-196.

Kerboeuf, D. (1978). The effects of time and temperature of storage on the infectivity of third-stage larvae of Heligmosomoides polygyrus (=Nematospiroides dubius) 1. Effects on the development to the adult stage in mice. Annales de Recherches Veterinaires 9, 153-159.

Khan, I. A., Hakak, R., Eberle, K., Sayles, P., Weiss, L. M. and Urban, J. F., Jr. (2008). Coinfection with Heligmosomoides polygyrus fails to establish CD8+ T-cell immunity against Toxoplasma gondii. Infection and Immunity 76, 1305-1313.

Koudandé, O. D., van Arendonk, J. A. M and Iraqi, F. (2005). Marker-assisted introgression of trypanotolerance QTL in mice. Mammalian Genome 16, 112-119.

Lewis, J. and Bryant, V. (1976). The distribution of Nematospiroides dubius within small intestine of laboratory mice. Fournal of Helminthology 50, 163-171.

Liu, S. K. (1965). Pathology of Nematospiroides dubius. I Primary infections in $\mathrm{C} 3 \mathrm{H}$ and Webster mice. Experimental Parasitology 17, 123-135.

Liu, S. K. (1966). Genetic influence on resistance of mice to Nematospiroides dubius. Experimental Parasitology 18, 311-319.

Maizels, R. M., Balic, A., Gomez-Escobar, N., Nair, M., Taylor, M. D. and Allen, J. E. (2004). Helminth parasites - masters of regulation. Immunological Reviews 201, 89-116.

McEwan, J. C., Dodds, K. G., Greer, G. J., Bain, W. E., Duncan, S. J., Wheeler, R., Knowler, K. J., Reid, P. J., Green, R. S. and Douch, P. G. C. (1995). Genetic estimates for parasite resistance traits in sheep and their correlations with production traits. New Zealand Fournal of Zoology 22, 177.

Menge, D. M., Behnke, J. M., Lowe, A., Gibson, J. P., Iraqi, F. A., Baker, L. and Wakelin, D. (2003).

Mapping of chromosomal regions influencing immunological responses to gastrointestinal nematode infections in mice. Parasite Immunology 25, 341-349.

Mitchell, G. F., Anders, R. F., Brown, G. V., Handman, E., Roberts-Thomson, I. C., Chapman, C. B., Forsyth, K. P., Kah1, L. P. and Cruise, K. M. (1982). Analysis of infection characteristics and antiparasite immune responses in resistant compared with susceptible hosts. Immunological Reviews 61, 137-188.

Mitchell, G. F. and Prowse, S. J. (1979). Three consequences of infection with Nematospiroides dubius in three inbred strains of mice. Fournal of Parasitology 65, 820-822.

Monroy, F. G. and Enriquez, F. J. (1992).

Heligmosomoides polygyrus: a model for chronic gastrointestinal helminthiasis. Parasitology Today $\mathbf{8}$, 49-54.

Morimoto, M., Morimoto, M., Whitmire, J., Xiao, S., Anthony, R. M., Mirakami, H., Star, R. A., Urban, J. F. Jr. and Gause, W. C. (2004). Peripheral CD4 T cells rapidly accumulate at the host: parasite interface during an inflammatory Th2 memory response. Fournal of Immunology 172, 2424-2430.

Njoroge, J. M., Scott, M. E. and Jalili, F. (1997). The efficacy of ivermectin against laboratory strains of Heligmosomoides polygyrus (Nematoda). International Fournal for Parasitology 27, 439-442.

Oliver, M. K., Telfer, S. and Piertney, S. B. (2009). Major histocompatibility complex (MHC) heterozygote superiority to natural multi-parasite infections in the water vole (Arvicola terrestris). Proceedings of the Royal Society of London, B 276, 1119-1128.

Panter, H. C. (1969). Host/parasite relationship of Nematospiroides dubius in the mouse. Fournal of Parasitology 55, 33-37.

Penn, D. J., Damjanovich, K. and Potts, W. K. (2002). MHC heterozygosity confers a selective advantage against multiple-strain infections. Proceedings of the National Academy of Sciences, USA 99, 11260-11264.

Peters, L. L., Robledo, R. F., Bult, C. J., Churchill, G. A., Paigen, B. J. and Svenson, K. L. (2007). The mouse as a model for human biology: a resource guide for complex trait analysis. Nature Reviews Genetics $\mathbf{8}$, 58-69.

Pleass, R. J. and Bianco, A. E. (1994). The role of adult worms in suppressing functional protective immunity to Heligmosomoides polygyrus bakeri challenge infections. Parasite Immunology 16, 619-628.

Pritchard, D. I., Ali, N. M. H. and Behnke, J. M. (1984). Analysis of the mechanism of immunodepression following heterologous antigenic stimulation during concurrent infection with Nematospiroides dubius. Immunology 51, 633-642.

Pritchard, D. I. and Behnke, J. M. (1985). The suppression of homologous immunity by soluble adult antigens of Nematospiroides dubius. Fournal of Helminthology 59, 251-256.

Prowse, S. J., Mitchell, G. F., Ey, P. L. and Jenkin, C. R. (1979). The development of resistance in different inbred strains of mice to infections with Nematospiroides dubius. Parasite Immunology 1, 277-288.

Quinnell, R., Behnke, J. M. and Keymer, A. E. (1991). Host specificity of and cross-immunity between two strains of Heligmosomoides polygyrus. Parasitology 102, 419-427.

Rhodes, M., Straw, R., Fernando, S., Evans, A., Lacey, T., Dearlove, A., Greystrong, J., Walker, J., Watson, P., Weston, P., Kelly, M., Taylor, D., Gibson, K., Mundy, C., Bourgade, F., Poirier, C., Simon, D., Brunialti, A. L., Montagutelli, X., 
Gu'enet, J. L., Haynes, A. and Brown, S. D. (1998). A high-resolution microsatellite map of the mouse genome. Genome Research 8, 531-542.

Rice, M. C. and O'Brien, S. J. (1980). Genetic variance of laboratory outbred Swiss mice. Nature, London 283, 157-161.

Robinson, M., Behnke, J. M. and Williams, D. J. L. (1988). Immunity to adult Heligmosomoides polygyrus (Nematospiroides dubius): survival or rejection of adult worms following transplantation to mice refractory to larval challenge. Fournal of Helminthology 62, 221-231.

Robinson, M., Wahid, F. N., Behnke, J. M. and Gilbert, F. S. (1989). Immunological relationships during primary infection with Heligmosomoides polygyrus (Nematospiroides dubius): dose-dependent expulsion of adult worms. Parasitology 98, 115-124.

Rzepecka, J., Donskow-Schmelter, K. and Doligalska, M. (2007). Heligmosomoides polygyrus infection down-regulates eotaxin concentration and CCR3 expression on lung eosinophils in murine allergic pulmonary inflammation. Parasite Immunology 29, 405-413.

Rzepecka, J., Lucius, R., Doligalska, M., Beck, S., Rausch, S. and Hartmann, S. (2006). Screening for immunomodulatory proteins of the intestinal parasitic nematode Heligmosomoides polygyrus. Parasite Immunology 28, 463-472.

Sakai, T., Kikkawa, Y., Miura, I., Inoue, T., Moriwaki, K., Shiroishi, T., Satta, Y., Takahata, N. and Yonekawa, H. (2005). Origins of mouse inbred strains deduced from whole-genome scanning by polymorphic microsatellite loci. Mammalian Genome 16, 11-19.

Segura, M., Su, Z., Piccirillo, C. and Stevenson, M. M. (2007). Impairment of dendritic cell function by excretory-secretory products : a potential mechanism for nematode-induced immunosuppression. European Fournal of Immunology 37, 1887-1904.

Shimp, R. G., Crandall, R. B. and Crandall, C. A. (1975). Heligmosomoides polygyrus (= Nematospiroides dubius): Suppression of antibody response to orally administered sheep erythrocytes in infected mice. Experimental Parasitology 38, 257-269.

Silver, L. (1995). Mouse Genetics. Oxford University Press, Oxford, UK. http://www.complextrait.org/ archive/2001/HTML/silverbook/index.shtml

Silver, L. (2008). Mouse Genetics; Concepts and Applications. The Jackson Laboratory, Bar Harbor, Maine, USA. http://www.informatics.jax.org/ silverbook/

Spurlock, G. M. (1943). Observations on host-parasite relations between laboratory mice and Nematospiroides dubius. Fournal of Parasitology 29, 303-311.

Stear, M. J., Innocent, G. T. and Buitkamp, J. (2005). The evolution and maintenance of polymorphism in the major histocompatibility complex. Veterinary Immunology and Immunopathology 108, 53-57.

Sukhdeo, M. V. K., O'Grady, R. T. and Hsu, S. C. (1984). The site selected by the larvae of Heligmosomoides polygyrus. Fournal of Helminthology 58, 19-23.

Suzuki, T., Ishih, A., Kino, H., Muregi, F. W., Takabayashi, S., Nishikawa, T., Takagi, H. and Terada, M. (2006). Chromosomal mapping of host resistance loci to Trichinella spiralis nematode infection in rats. Immunogenetics 58, 26-30.

Tang, J., Dobson, C. and McManus, D. P. (1995). Phenotypes of Heligmosomoides polygyrus selected to survive protective immunity in Quackenbush mice. Fournal of Parasitology 81, 900-904.

Telford, G., Wheeler, D. J., Appleby, P., Bowen, J. G. and Pritchard, D. I. (1989). Heligmosomoides polygyrus immunomodulatory factor (IMF) targets Tlymphocytes. Parasite Immunology 20, 601-611.

Tenora, F. and Barus, V. (2001). Synonymy of the nematode Heligmosomoides polygyrus (Heligmosomidae) and notes on the validity of related species. Helminthologia 38, 176.

Tenora, F., Barus, V. and Prokes, M. (2003). Notes to the species Heligmosomoides polygyrus (Dujardin, 1845) (Nematoda, Heligmosomidae), parasitizing rodentia. Acta Universitatis Agriculturae et Silviculturae Mendelianae Brunensis 51, 7-18.

The Wellcome Trust Case Control Consortium (2007). Genome-wide association study of 14,000 cases of seven common diseases and 3,000 shared controls. Nature, London 447, 661-678.

Tsang, S., Sun, Z., Luke, B., Stewart, C., Lum, N., Gregory, M., Wu, X., Subleski, M., Jenkins, N. A., Copeland, N. G. and Munroe, D. J. (2005). A comprehensive SNP-based genetic analysis of inbred mouse strains. Mammalian Genome 16, 476-480.

van Zandt, P. D. (1961). Studies on the immunity relationship in white mice given infections with Nematospiroides dubius Baylis, 1926 (Nematoda: Heligmosomidae). Fournal of the Elisha Mitchell Scientific Society 77, 300-309.

Wahid, F. N. and Behnke, J. M. (1992). Stimuli for acquired resistance to Heligmosomoides polygyrus from intestinal tissue resident L 3 and L4 larvae. International Fournal for Parasitology 22, 699-710.

Wahid, F. N. and Behnke, J. M. (1993). Immunological relationships during primary infection with Heligmosomoides polygyrus: regulation of fast response phenotype by H-2 and non H-2 genes. Parasitology 107, 343-350.

Wahid, F. N. and Behnke, J. M. (1996). Genetic control of acquired resistance to Heligmosomoides polygyrus: overcoming genetically determined weak responder status by strategic immunization with ivermectinabbreviated infections. Fournal of Helminthology 70, 159-168.

Wahid, F. N., Behnke, J. M., Grencis, R. K., Else, K. J. and Ben-Smith, A. W. (1994). Immunological relationships during primary infection with Heligmosomoides polygyrus: Th2 cytokines and primary response phenotype. Parasitology 108, 461-471.

Wahid, F. N., Robinson, M. and Behnke, J. M. (1989). Immunological relationships during primary infection with Heligmosomoides polygyrus (Nematospiroides dubius): expulsion of adult worms from fast responder syngeneic and hybrid strains of mice. Parasitology 98, 459-469.

Wakelin, D. (1978). Genetic control of susceptibility and resistance to parasitic infection. Advances in Parasitology 16, 219-308.

Wakelin, D. and Blackwell, J. M. (1988). Genetics of Resistance to Bacterial and Parasitic Infections. Taylor and Francis, London, UK. 
Wassom, D. L., Brooks, B. O., Cypess, R. H. and David, C. S. (1983). A survey of susceptibility to infection with Trichinella spiralis of inbred mouse strains sharing common $\mathrm{H}-2$ alleles but different genetic backgrounds. Fournal of Parasitology 69, 1033-1037.

Wassom, D. L. and Kelly, E. A. B. (1990). The role of the histocompatibility complex in resistance to parasite infections. Critical Reviews in Immunology 10, $31-52$.

Wassom, D. L., Wakelin, D., Brooks, B. O., Krco, C. J. and David, C. S. (1984). Genetic control of immunity to Trichinella spiralis infection of mice. Hypothesis to explain the role of $\mathrm{H}-2$ genes in primary and challenge infections. Immunology 51, 625-631.

Watanabe, N., Ishiwata, K., Kaneko, S., Oku, Y., Kamiya, M. and Katakura, K. (1993). Immune defense and eosinophilia in congenitally IgE-deficient SJA/9 mice infected with Angiostrongylus costaricensis. Parasitology Research 79, 431-434.

Wegner, K. M., Reusch, T. B. H. and Kalbe, M. (2003). Multiple parasites are driving major histocompatibility complex polymorphism in the wild. Fournal of Evolutionary Biology 16, 224-232.
Wicker, L. S., Chamberlain, G., Hunter, K., Rainbow, D., Howlett, S., Tiffen, P., Clark, J., GonzalezMunoz, A., Cumiskey, A. M., Rosa, R. L., Howson, J. M., Smink, L. J., Kingsnorth, A., Lyons, P. A., Gregory, S., Rogers, J., Todd, J. A. and Peterson, L. B. (2004). Fine mapping, gene content, comparative sequencing, and expression analyses support Ctla 4 and Nramp1 as candidates for Idd5.1 and Idd5.2 in the nonobese diabetic mouse. Fournal of Immunology 173, 164-173.

Wilson, M. S., Taylor, M. D., Balic, A., Finney, C. A., Lamb, J. R. and Maizels, R. M. (2005). Suppression of allergic airway inflammation by helminth-induced regulatory T cells. Fournal of Experimental Medicine 202, 1199-1212.

Zaralis, K., Tolkamp, B. J., Houdijk, J. G. M., Wylie, A. R. G. and Kyriazakis, I. (2008). Changes in food intake and circulating leptin due to gastrointestinal parasitism in lambs of two breeds. Fournal of Animal Science 86, 1891-1903.

Zhong, S. and Dobson, C. (1996). Heligmosomoides polygyrus: resistance in inbred, outbred and selected mice. Experimental Parasitology 82, 122-131. 